\title{
SUBSEQUENT EVENTS AND THEIR IMPORTANCE IN DRAWING UP ANNUAL FINANCIAL STATEMENTS
}

\author{
Daniel Botez \\ "Vasile Alecsandri" University of Bacău \\ daniel6331@yahoo.com
}

\begin{abstract}
Subsequent events, called so because they are recorded after the closing date of financial year, must be recorded and taken into account in drawing up the financial statements. Some of them can fundamentally changing financial position of the entity or provide information to users absolutely necessary for their decisions. Accounting treatment in this situation is provided for by International Standard of Accounting ISA 10 "Events after the Reporting Period", whose provisions are taken to a large extent in national accounting standards. For financial auditor, investigating how the subsequent events are presented in the financial statements shall constitute a procedural obligation. Auditor`s procedure is based on the provisions of an specific International Standard on Auditing, ISA 560 "Subsequent events". He shall be required to satisfy itself that in the financial statements shall be presented all treatment and appropriate information concerning subsequent events.
\end{abstract}

\section{Keywords}

subsequent events; financial statements; financial audit

\section{JEL Classification}

M40; M42

\section{Subsequent events through the prism of accountants}

From an accounting point of view, the treatment of subsequent events is provided for by International Accounting Standard IAS 10 "Events after the Reporting Period". The objective of standard is to prescribe when an entity should adjust its financial statements for subsequent balance sheet date events and presentation of information which should be an entity with regard to the date on which it has been authorized publication of financial statements with respect to the events after the balance sheet date.

Direct consequence is that an entity should not be to draw up financial statements on the basis of assumptions concerning business continuity if subsequent events indicates that this assumption in not suitable.

Subsequent events are those events, both favorable and unfavorable, which occur between balance sheet date and the date on which it has authorized its publication financial statements.

May be identifies two types of events:

1. Those which are proof of the conditions that existed to the balance sheet date (subsequent events which lead to adjust financial statements); and

2. Those which provide information on conditions that may arise after the date of balance sheet (subsequent events that does not lead to an adjustment of financial statements).

Subsequent events shall include all events up to the date on which it is necessary to authorize publication of financial statements, even if those events taking place after public declaration of profit or other financial information selected. 
An entity is to adjust the amounts recognized in its financial statements to reflect subsequent events when they bring new information relating to situation existing at the time of closing financial year. For example, settlement of a dispute on court judgment. Also, bankruptcy a customer for whom the entity had an adjustment for depreciation led directly to its registration.

An entity shall not be required to adjust the amounts recognized in its financial statements to reflect subsequent events that do not lead to adjustment financial statements. In this situation subsequent events must be presented in note. For example, events which call into question a problem concerning business continuity.

\section{Subsequent events through the prism of financial auditor}

From the point of view of financial auditor, such intervention on subsequent events is provided for by International Standard on Auditing ISA 560 "Subsequent events".

Auditor`s objective are:

A) Obtaining sufficient appropriate audit evidence on the extent to which events occurring between the date of financial statements and auditor`s report date which provide for an adjustment or the presentation in the financial statements are reflected, as appropriate, in those financial statements, in accordance with the general financial reporting applicable framework; and

B) The provisions of answers appropriate to the deeds of which the auditor becomes aware after the auditor`s report date, which, if it had been known to the auditor at that time, could have been determined the auditor to modify auditor1s report.

The auditor also should perform audit procedures designed to obtain sufficient appropriate audit evidence, according to which events occurring between the date of financial statements and auditor1s report date which provide for an adjustment or the presentation in the financial statements have been identified.

In accordance with the assessment of the risk by auditor, audit procedures may include procedures necessary to obtain sufficient appropriate audit evidence, which involves a review or test accounting records or transactions which take place between the date of financial statements and auditor`s report date.

The auditor shall carry out the procedures designed to obtain sufficient evidence as appropriate so that they cover the period between the date of financial statements and auditor`s report date, as far as possible, as close as possible to the data. The auditor also has to take into account the risk assessment by auditor in determination of the nature and extent of such audit procedures, which should include the following:

A) Obtain an understanding of any proceeding on which the management has established to ensure that the subsequent events are identified;

B) Inquiry management, and where appropriate, persons charged with governance, with regard to the production any further event that could affect financial statements;

C) The reading minutes, if any, of entity owners meetings, management and persons charged with governance which took place after the date of financial statements query with regard to the matters discussed at such meetings for which there are not yet available minutes.

D) The reading of most recent interim financial statements for entity, if there is one.

If, as result of procedures carried out the auditor identifies events that provide for an adjustment or presentation in the financial statements, the auditor must be able to determine so far as such an event is reflected, as appropriate, in those financial statements, in accordance with the general financial reporting applicable framework. 


\section{Case study}

The Company ABC closed financial year to 31 December 2013. General meeting of shareholders has been convened for 28 February 2014.

The threshold of materiality for financial statements as a whole was fixed by auditor at $100.000 \mathrm{RON}$.

For the first time on 20 February it is found that:

1. On 14 January 2014, has been identified a significant fraud. Debts in the amount of $125.000 \mathrm{RON}$, recorded in the accounts of fictitious suppliers have been paid in bank accounts established by an employee of the company. Events have occurred within the last seven months. The employee was dismissed immediately; they have been initiated legal proceedings against him.

The employee has recorded in placeholder different services on behalf of expenditure in services from a third party. Fictitious bills did not include VAT.

$628 \quad=\quad 401$

Other expenses with third party Suppliers

125.000

After he operated fictitious payment in the accounts, where he raised money.

401

Suppliers
5121

Bank account

125.000

2. On 20 December 2013, a customer has initiated legal proceedings against the company in relation to a breach of contract. On 29 December 2013, the lawyers of entity has announced that is unlikely that it will be found responsible; therefore they have not been adjusted financial statements, but the situation was presented in notes. On 29 January 2014, the court found the company responsible for breaking a contractual clause and established payment of damages amounting to $130.000 \mathrm{RON}$. Products supplied, worth 200.000 RON, have been returned.

Sale of the products has been registered under normal conditions

$\begin{array}{ccc}4111 & \% & 238.000 \\ \text { Customers } & 701 & 200.000 \\ & \text { Revenue from sale } & \\ & 4427 & 38.000 \\ & \text { Output VAT } & \end{array}$

3. On 19 February 2014, a customer has ceased its activity by financial difficulties. He has a debt to the company of 2.500 RON. The board of directors considered that the amount is not relevant and established that is not necessary to adjust.

Debt instruments has been registered as normal commercial operation

4111

Customers

\section{$=$}

$\%$
701
Revenue from sale
4427

Output VAT
2.500

2.101

399

\section{Procedures carried out by the management}

As results of these findings, the management company has taken following steps:

1. Fraud was committed by the employee during the course of the financial year. Fraud, errors and irregularities that appear before the date of end-of-year but that are discovered only beyond the year closed suppose adjusting elements and, therefore, 
financial statements would need to be modified according to the fraudulent activity to the end of the year.

To highlight this fact the entity registered a claim on former employee with the value of 125.000 RON.

461

Sundry debtors
754

Debtors income
125.000

by correcting such result for the year.

2. At the end of the year, the company of such entry in notes about the debt was lacking. However, after the end of the financial year, the court found the company liable for breach of contract. Judicial procedure was initiated on 20 December 2013 (with 10 days before the end of financial year). They were, therefore, evidence about the conditions existing at the end of the year. IAS 10 requires that these conditions are to be taken into account in order to determine whether or not you have recognized a debt. In this case, financial statements require an adjustment for that has been fulfilled criteria for the recognition of a provision for litigation. As a result, the entity has amended financial statements by recording a provision for litigation in value of $130.000 \mathrm{RON}$ and corrected information properly in the explanatory notes.

6812

Expenses
1511

Provisions for litigations
130.000

3. Cessation of a client to a recent date from the date of closure of the exercise indicates a high probability of unpaid and represents, therefore, a further event. As a result, had to be recorded an adjustment for doubtful debts of $2.500 \mathrm{RON}$, but the entity considered amount irrelevant and did not change their accounts.

\section{Procedures carried out by the financial auditor}

Fraud, risk factors of fraud are referred to into International Standard on Auditing ISA 240 "Auditor`s responsibility for fraud in an audit of financial statements". That fraud has taken place within entity increases the risk of material misstatement due to fraud. As a result, the auditor must apply supplementary procedures. Audit procedures which must be carried out in order to ensure that fraud has been correctly identified and accounted in the financial statements include:

- Recalculation of sums involved;

In doing the recalculation values laid down by the entity, the auditor also carried out investigations and found out that the amount of 50.000 RON representing fictitious payment has not been included in the accounts drawn up by that entity.

- Discussions with the management of the way in which such a fraud took place and why it took seven months to discover fraud (controls should be able to prevent, detect and correct material distortions in a short period of time);

By reviewing and applying supplementary procedures for the assessment of internal control, the auditor finds that there is a procedure to provide that payments must be approved by at least two persons and that any new supplier must be assessed by an assessment record. The establishment in circumstances in which the accounting officer has discovered fraud and what working procedures and control (if equipped) contain weaknesses that have allowed employee to commit fraud by this procedure the auditor also found what are the weaknesses of the system of internal control which permitted that the fraud is discovered so late.

- Perform procedures by the fund on operations in the vicinity of closing the long entries (in particular those close together, or at the end of the year); 
- Confirm directly with the suppliers of the balances and transactions for the period covered by audit as a result of carrying out these procedures have not been found errors;

- Review invoices for the purchase and increase professional skepticism and investigation with respect to their authenticity;

- Review files relating to human resources to find evidence of disciplinary proceedings taken against employee. This will also confirm compliance with laws and regulations, in particular in relation to the present legislation employment and retention of funds;

- Testing of controls to identify any other weaknesses which may indicate management employees or fraud;

- Obtaining written statements from management on fraud issues;

- Discussions with the lawyer's entity with regard to the possibility of recover funds diverted.

\section{Measures, as determined by auditor on fraud issues}

- Additional adjustment of the financial statements by the recording of additional claims on an employee for fraud of 50.000 RON

461

Sundry debtors
754

Debtors income

50.000

- Inclusion in your letter to those charged with governance weaknesses have been observed with regard to internal control.

\section{Procedures carried out by auditor on judicial proceedings}

- Obtaining a copy of the judgment and other correspondence confirming that the entity has been found guilty and must pay for damage customer or verification of confirmation of payment to the customer;

- To ensure that a provision has already been admitted to the original decision of the company;

- To ensure that the value of provision is reasonable in relation to its judgment;

- Obtaining a written statement from management by confirming treatment of provision. Completing letter concerning statements made in writing by management in accordance with International Standard on Auditing ISA 580 "Written representation" with his opinion on his guilt and the confirmation of lodging entity provision.

\section{Procedures carried out by auditor on uncertain}

- Discuss customer management reason for which an adjustment has not been registered;

- Finds that the amount in question in immaterial for financial statements and, under the circumstances in which this amount remains immaterial and at the stage of completion, to express an unqualified opinion;

- Adjusting financial statements by the formation of a provision for doubtful debts customer for 2.500 RON.

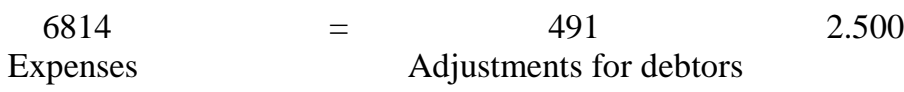




\section{References}

Accounting Reglementations in accordance with the European directives, approved by OMFP 3055/2009, with completions and modifications.

CECCAR (2010), Guide for application OMFP 3055/2009, Bucharest.

International Accounting Standard IAS 10 "Events after the Reporting Period". International Standard on Auditing ISA 560 "Subsequent events". 